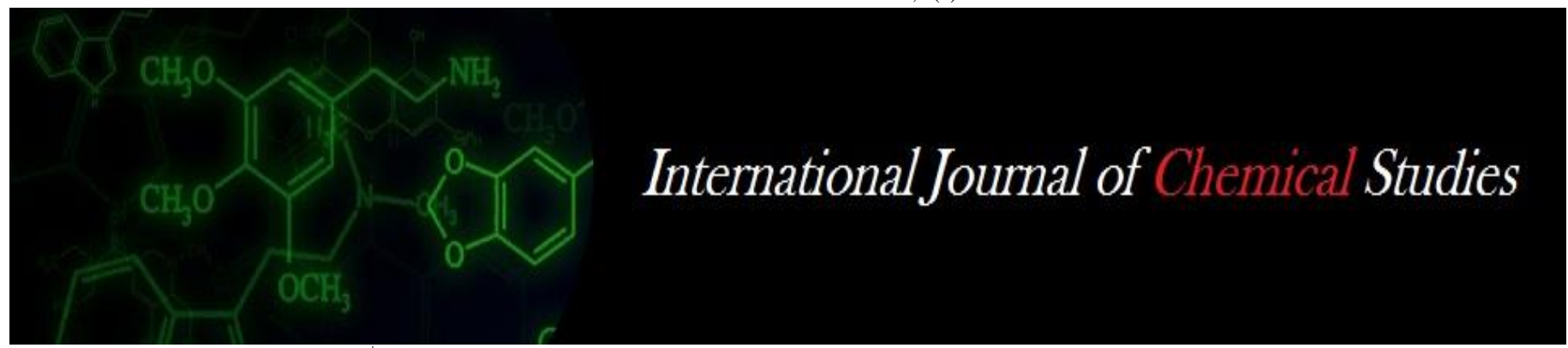

P-ISSN: 2349-8528

E-ISSN: 2321-4902

IJCS 2020; 8(1): 2194-2197

(C) 2020 IJCS

Received: 19-11-2019

Accepted: 21-12-2019

Yasodha M

Asst. Professor (Agronomy),

Vanavarayar Institute of

Agriculture, Tamil Nadu, India

Devasenapathy $\mathbf{P}$

Retd. Professor (Agronomy),

Tamil Nadu Agricultural

University, Coimbatore, Tamil

Nadu, India

Ramalakshmi A

Asst. Professor (Agrl.

Microbiology), Tamil Nadu

Agricultural University,

Coimbatore, Tamil Nadu, India
Corresponding Author:

Yasodha M

Asst. Professor (Agronomy),

Vanavarayar Institute of

Agriculture, Tamil Nadu, India

\section{Effect of arbuscular mycorrhiza on growth and yield of lowland rice ecosystem}

\author{
Yasodha M, Devasenapathy P and Ramalakshmi A
}

DOI: https://doi.org/10.22271/chemi.2020.v8.i1ag.8594

\begin{abstract}
A field experiment was conducted with rice $\mathrm{CO}(\mathrm{R}) 51$ at Tamil Nadu Agricultural University, Coimbatore. There were ten treatment combinations replicated thrice in Randomized Block Design. The treatments comprised of recommended dose of fertilizers (RDF) NPK (150:50:50) kg/ha, ZnSO 4 @ 25 $\mathrm{kg} / \mathrm{ha}$ as soil application as well as foliar spray @ 0.5\%, 30 per cent of previous crop residue was incorporated as paddy straw @ $3.8 \mathrm{t} / \mathrm{ha}$, Arbuscular Mycorrhiza (AM) @ $50 \mathrm{~kg} / \mathrm{ha}$. The maximum plant height $(99.7 \mathrm{~cm})$, dry matter production $(12,478 \mathrm{~kg} / \mathrm{ha})$, grain yield $(6,677 \mathrm{~kg} / \mathrm{ha})$ and $\mathrm{B}: \mathrm{C}$ ratio $(2.81)$ were recorded significantly higher in $\mathrm{RDF}+\mathrm{AM}+$ residue incorporation $+\mathrm{ZnSO}_{4}$ foliar spray over farmers practices of RDF alone and was nearly followed by application of $\mathrm{RDF}+\mathrm{AM}+$ residue incorporation $+\mathrm{ZnSO}_{4}$ soil application.
\end{abstract}

Keywords: Arbuscular mycorrhizae, zinc sulphate, enzymatic activities

\section{Introduction}

Rice (Oryza sativa L.) is a staple food crop of Asia in general and India in particular. It is being grown over an area of $43.95 \mathrm{~m}$ ha with a production of $106.54 \mathrm{~m} \mathrm{t}$ of grain (Agricultural statistics at a Glance, 2015) ${ }^{[1]}$ and it continues to hold the key to sustain food production by contributing agriculture GDP. Plants require both macro and micronutrients. Among these nutrients, the micronutrients are taken by the plant in small amount hence its deficiency increases with intensive cultivation. $\mathrm{Zn}$ is a major component and activator of several enzymes involved in plant metabolic activities. Limited amount of soluble $\mathrm{Zn}$ in soil causes $\mathrm{Zn}$ deficiency. On an average 40 per cent of Indian soils (Takkar, 1996) ${ }^{[15]}$ and 50 to 58 per cent of TN soils (Muthukumararaja and Sriramachandrasekaran, 2012; Singh, 2001) ${ }^{[8,14]}$ are deficient in Zn. Zinc deficiency is a serious constraint in many parts of the world and this could only be compensated by the application of costly chemical fertilizers, either as foliar or soil application of zinc (Reyes \& Brinkman, 1989) ${ }^{[11]}$.

An Arbuscular Mycorrhizal fungus (AMF) is a type of Mycorrhiza in which the fungus penetrates the cortical cells of the roots of a vascular plant and it helps the plants to capture nutrients such as $\mathrm{P}, \mathrm{S}, \mathrm{N}, \mathrm{Zn}$ and micronutrients from the soil and enhances plant growth by mobilisation. It was reported that rice plants readily form mycorrhizal associations under upland conditions, hence under submerged conditions infection is rare due to the anoxic environment (Ilag et al., 1987). Barea (1991) ${ }^{[5,2]}$ reported, however, that AMF can survive in waterlogged conditions, and this is supported by the fact that Glomus etunicatum, showed fairly high colonization in rice roots and best survival under submerged conditions (Purakayastha and Chhonkar, 2001) ${ }^{[10]}$.

Crop residue still plays an important role in the cycling of nutrients despite the dominant role of chemical fertilizers in crop production. Crop residues like paddy straw are vital natural resources for sustaining rice soil productivity. With using the biofertilizers, organic sources and chemical fertilizers, a low input system can be carried out and it can be help in achieving sustainability of farms, which results in sustaining higher crop productivity, improving soil quality, and productivity on long-term basis.

\section{Materials and Methods}

A field experiment was conducted to evaluate the growth and yield of rice during kharif (Aug to Dec) under puddled lowland ecosystem at Tamil Nadu Agricultural University, Coimbatore. 
The variety used was $\mathrm{CO}(\mathrm{R}) 51$. There were ten treatments and it was replicated thrice in Randomized Block Design. The soil of the experimental field was clay loam in texture with a $\mathrm{pH}$ of 8.10 and $\mathrm{EC}$ of $0.40 \mathrm{dS} / \mathrm{m}$. The nutrient status of the soil was low in available nitrogen $(235 \mathrm{~kg} / \mathrm{ha})$, medium in available phosphorus (16 kg/ha) and high in available potassium $(528 \mathrm{~kg} / \mathrm{ha})$. The ten treatments consisted of $\mathrm{T}_{1}$ : Recommended Dose of fertilizer (RDF)- 150:50:50 kg NPK/ha, $\mathrm{T}_{2}: \mathrm{T}_{1}+\mathrm{ZnSO}_{4} @ 25 \mathrm{~kg} / \mathrm{ha}-$ Basal, $\mathrm{T}_{3}: \mathrm{T}_{1}+\mathrm{ZnSO}_{4}$ @ $0.5 \%$ on 30 and $40 \mathrm{DAT}, \mathrm{T}_{4}: \mathrm{T}_{1}+$ Residue incorporation, $\mathrm{T}_{5}: \mathrm{T}_{4}+\mathrm{ZnSO}_{4} @ 25 \mathrm{~kg} / \mathrm{ha}-\mathrm{Basal}, \mathrm{T}_{6}: \mathrm{T}_{4}+\mathrm{ZnSO}_{4} @ 0.5 \%$ on 30 and $40 \mathrm{DAT}, \mathrm{T}_{7}: \mathrm{T}_{1}+$ Arbuscular Mycorrhiza (50 $\mathrm{kg} / \mathrm{ha}), \mathrm{T}_{8}: \mathrm{T}_{7}+$ Residue incorporation, $\mathrm{T}_{9}: \mathrm{T}_{8}+\mathrm{ZnSO}_{4} @ 25$ $\mathrm{kg} / \mathrm{ha}-$ Basal, $\mathrm{T}_{10}: \mathrm{T}_{8}+\mathrm{ZnSO}_{4} @ 0.5 \%$ on 30 and $40 \mathrm{DAT}$.

The nitrogen was applied in three splits viz., Basal (B), at Active Tillering (AT) and Panicle Initiation (PI) stages. The phosphorous and potassium fertilizers were applied basally. Previous paddy residue was incorporated at 30 per cent before transplanting. AM developed by department of agricultural microbiology, TNAU and the species used was Glomus intraradices and it was inoculated @ $5 \mathrm{~g} / \mathrm{m}^{2}$ both in nursery and in main field. SRI water management was adopted for irrigation. Irrigation was withheld seven days before harvest. Biometric observations were recorded as per the guidelines stipulated by the All India Co-ordinated Rice Improvement Project (Haveten, 1977) ${ }^{[4]}$. Five plants in each plot were selected at random and tagged. These plants were used for recording biometric observations at different stages of crop growth. Plant height was measured at AT, PI, harvest stages and it is expressed in $\mathrm{cm}$. Five hills were selected at random from each plot in the sampling area. The collected samples were air dried, then oven dried at $80^{\circ} \mathrm{C}$ for 72 hours and dry matter production/ha was calculated and expressed in $\mathrm{kg} / \mathrm{ha}$. Grains from net plot were cleaned, sun dried and weighed at 14 per cent moisture content. After separating the grains the left over straw from the net plot was sun dried and weighed. Both grain and straw yield was calculated and expressed in $\mathrm{kg} / \mathrm{ha}$. The data on various characters studied during the course of investigation were statistically analyzed as suggested by Gomez and Gomez (1984) ${ }^{[3]}$.

\section{Result and Discussion \\ Growth component}

The plant height, an important growth component in rice, varied significantly with different treatments. Application of $\mathrm{AM}$ in combination with residue incorporation and soil application of Zinc Sulphate recorded taller plants $(51 \mathrm{~cm})$ at tillering stage. This might be due to adequate supply of zinc which contributed to accelerate the enzymatic activity and auxin metabolism in plants. Similar results were also obtained by Maqsood et al. (1999) ${ }^{[7]}$.

AM in combination with residue incorporation and foliar spray of Zinc Sulphate exerted a positive influence on the growth characters and recorded taller plants at PI $(76.3 \mathrm{~cm})$ and harvest stages $(99.7 \mathrm{~cm})$. This might be due to better availability of macro, micro, organic matter nutrients in adequate quantities along with efficient bio inoculants. The foliar spray of Zinc Sulphate increases the accumulation of chlorophyll content that leads a way to increase in plant height. These findings are in accordance with the line of Lindsay (1974) [6]. Mycorrhiza treatment significantly increased the plant height at 30,60 DAT and harvest than the non mycorrhizal treatment. The present results are in accordance with that of Tarafdar and Marschner (1994) ${ }^{[16]}$ who concluded that mycorrhizal plants performed better in terms of plant height. Minimum plant height at PI $(65.1 \mathrm{~cm})$ and harvest stage $(83.4 \mathrm{~cm})$ was recorded in $\mathrm{RDF}\left(\mathrm{T}_{1}\right)$ alone (Fig.1).

The dry matter production (DMP) increased with the age of the crop and reached the higher at harvest. With regard to DMP it was higher with mycorrhizal inoculation. At active tillering, $\mathrm{RDF}+\mathrm{AM}+$ Residue incorporation $+\mathrm{ZnSO}_{4}$ soil $\left(\mathrm{T}_{9}\right)$ recorded higher dry matter production (1392 kg/ha) followed by other AM applied plots. This might be due to the soil application of Zinc Sulphate that significantly increased the inflow of $\mathrm{Zn}$ to rice roots. At panicle initiation and harvest stages, treatments receiving AM recorded higher dry matter production compared to all the other treatments (Fig.2). Lower DMP at PI (4971 kg/ha) and harvest stage (7078 $\mathrm{kg} / \mathrm{ha}$ ) was recorded in RDF alone $\left(\mathrm{T}_{1}\right)$.

\section{Yield}

Yield of the plant depends not only on crop plant alone hence also on its physical, chemical environment and biological interactions. Most of the growth and yield components significantly responded to AM in combination with residue incorporation. Higher grain yield of $6677 \mathrm{~kg} / \mathrm{ha}$ was observed in $\mathrm{RDF}+\mathrm{AM}+$ Residue incorporation $+\mathrm{ZnSO}_{4}$ foliar $\left(\mathrm{T}_{10}\right)$. Lower grain yield of $4650 \mathrm{~kg} / \mathrm{ha}$ was recorded in RDF $\left(\mathrm{T}_{1}\right)$. Their combined effect contributed to the increased grain yield. Foliar spray of zinc that caused direct absorption of $\mathrm{Zn}$ in available form as zinc is attributed to its involvement in many metallic enzyme system, regulatory functions and auxin production (Sachdev et al., 1988) ${ }^{[12]}$, enhanced synthesis of carbohydrates and their transport to the site of grain production (Pedda Babu et al., 2007) ${ }^{[9]}$. Higher nutrient uptake by AM mobilization and stubble incorporation was attributed to the increased and gradual release of nutrients from the residues during the process of decomposition might have increased the grain yield (Table.1). A trend similar to that in grain yield was observed in straw yield also. The reasons attributed for increased grain yield hold good for straw yield also.

\section{Conclusion}

From the experiment, it is inferred that application of Arbuscular Mycorrhiza in combination with residue incorporation and foliar spray of zinc sulphate could be the best sustainable nutrient management practice for lowland rice environment for getting sustainable yield and higher returns. 


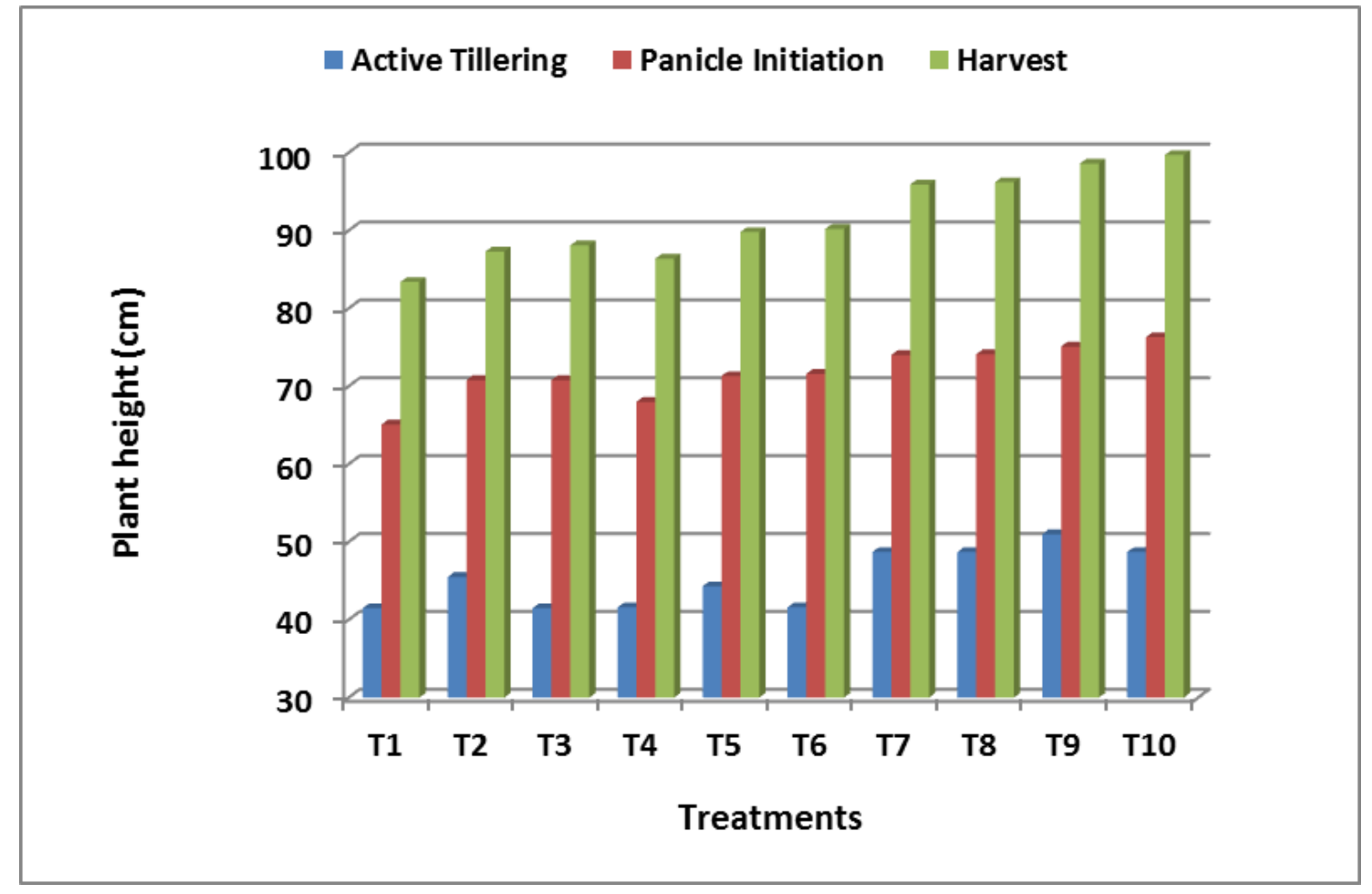

Fig. 1: Effect of Arbuscular mycorrhiza, residue incorporation and zinc fertilizer application on plant height (cm) of rice at Active tillering, Panicle initiation and harvest stages

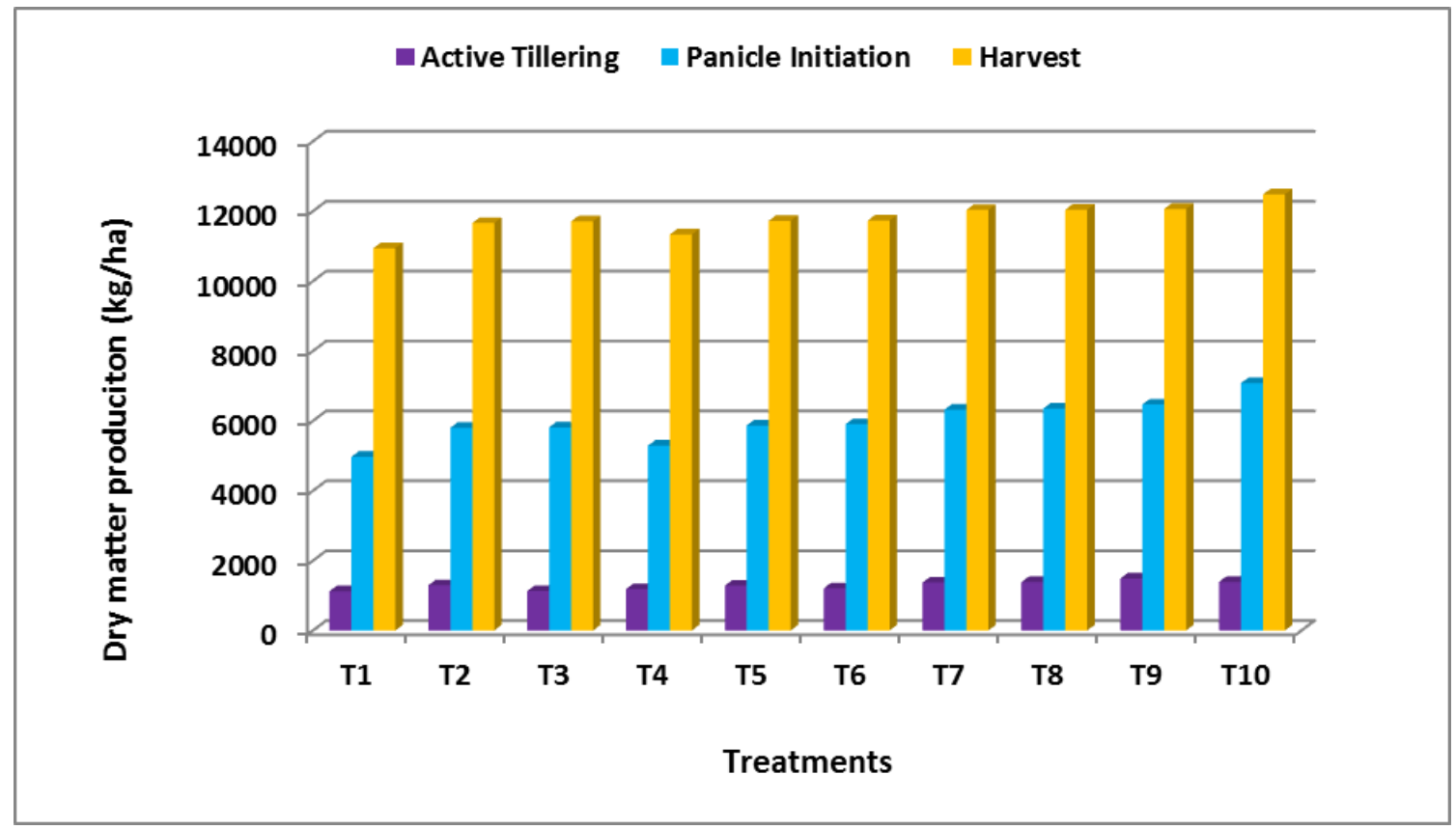

Fig. 2: Effect of Arbuscular mycorrhiza, residue incorporation and zinc fertilizer application on dry matter production (kg/ha) of rice at Active tillering, Panicle initiation and harvest stages

Table 1: Effect of Arbuscular mycorrhiza, residue incorporation and zinc fertilizer application on yield and economics of rice

\begin{tabular}{|c|c|c|c|c|}
\hline $\mathbf{T}_{\mathbf{n}}$ & Treatments & Grain yield & Straw yield & B:C ratio \\
\hline $\mathrm{T}_{1}$ & RDF - 150:50:50 kg NPK/ha & 4650 & 5891 & 2.26 \\
\hline $\mathrm{T}_{2}$ & $\mathrm{RDF}+\mathrm{Zn}$ soil $\left(\mathrm{ZnSO}_{4} @ 25 \mathrm{~kg} / \mathrm{ha}-\mathrm{Basal}\right)$ & 5116 & 6190 & 2.35 \\
\hline $\mathrm{T}_{3}$ & $\mathrm{RDF}+\mathrm{Zn}$ foliar $\left(\mathrm{ZnSO}_{4} @ 0.5 \%\right.$ on $\left.30 \& 40^{\text {th }} \mathrm{DAT}\right)$ & 5121 & 6227 & 2.43 \\
\hline $\mathrm{T}_{4}$ & RDF + Residue incorporation ( $30 \%$ of the previous crop residue) & 5014 & 5967 & 2.34 \\
\hline $\mathrm{T}_{5}$ & RDF + Residue incorporation $+\mathrm{Zn}$ soil & 5329 & 6329 & 2.37 \\
\hline $\mathrm{T}_{6}$ & RDF + Residue incorporation + Zn foliar & 5378 & 6337 & 2.46 \\
\hline $\mathrm{T}_{7}$ & $\mathrm{RDF}+\mathrm{AM}$ & 6346 & 7253 & 2.79 \\
\hline $\mathrm{T}_{8}$ & RDF + AM + Residue incorporation & 6422 & 7403 & 2.76 \\
\hline $\mathrm{T}_{9}$ & RDF + AM + Residue incorporation + Zn soil & 6576 & 7431 & 2.70 \\
\hline $\mathrm{T}_{10}$ & RDF + AM + Residue incorporation + Zn foliar & 6677 & 7496 & 2.81 \\
\hline & $\mathrm{CD}(\mathrm{P}=0.05)$ & 336 & 389 & $\begin{array}{ll}------ \\
\end{array}$ \\
\hline
\end{tabular}




\section{References}

1. Agricultural statistics at a Glance. Directorate of economics and statistics, Government of India, 2015, 1024.

2. Barea JM. Vesicular-arbuscular mycorrhizae as modifiers of soil fertility. Advances in Soil Science. SpringerVerlag, New York, 1991, 1-40.

3. Gomez KA, Gomez AA. Statistical Procedures for Agrl. Research. II Ed., John Wiley and Sons., New york, 1984, 381.

4. Haveten. Outlines for filling out the coding forms. All India Co-ordinated Rice improvement Project, Rajendranagar, Hyderabad, India, Mimeo, 1977, 89.

5. Ilag LL, Rosales AM, Elazegui FA, Mew TW. Changes in the populations on infective endomycorrhizal fungi in a rice-based cropping system. Plant Soil. 1987; 103:6773.

6. Lindsay WL. Zinc in soils and plant nutrition. Adv. Agron. 1974; 24:147-181

7. Maqsood M, Irshad M, Wajid SA, Hussain H. Growth and yield response of Basmati-385 (Oryza sativa L.) to $\mathrm{ZnSO}_{4}$ application. Pak. J Biol. Sci. 1999; 2(4):16321633.

8. Muthukumararaja TM, Sriramachadrasekharan. Effect of zinc on yield, zinc nutrition and zinc use efficiency of management measure on wetland rice productivity in a zinc-deficient soil. Philippine J Crop Sci. 2012; 61:7-13.

9. Pedda Babu P, Shanti M, Rajendra Prasad B, Minhas PS. Effect of zinc on rice in rice-black gram cropping system in saline soils. Andhra Agric. J. 2007; 54(1\&2):47-50.

10. Purakayastha TJ, Chhonkar PK. Influence of vesiculararbuscular mycorrhizal fungi (Glomus etunicatum L.) on mobilization of $\mathrm{Zn}$ in wetland rice (Oryza sativa L.). Biology and Fertility of Soils. 2001; 33:323-327.

11. Reyes RY, Brinkman R. The effect of zinc application and other land and crop management measure on wetland rice productivity in a zinc deficient soil. Philippine $\mathbf{J}$ Crop Sci. 1989; 61:7-13.

12. Sachdev P, Dep DL, Rostogi DK. Relative performance of mono and hepta hydrate zinc sulphate in calcaereous soil. Dep. Soil Sci., Rajendra Agric Univ. Indian Fertilizer News. 1988; 32:3-45.

13. Schmidt GM, Laskowski S. Phosphate ester cleavage (Survey). In: Boyer PD, Lardy H, Myrback K (Eds). The enzymes, 2nd edn. Academic Press, New York, 1961, 335.

14. Singh MV. Evaluation of micronutrient stocks in different agroecological zones of India. Indian $\mathbf{J}$ Fertilizer. 2001; 46:25-42.

15. Takkar PN. Micronutrient research and sustainable agriculture productivity in India. J Indian Soc. Soil Sci. 1996; 44:562-581.

16. Tarafdar JC, Marschner HH. Efficiency of VAM hyphae in utilization of organic phosphorous by wheat plants. Soil Sci. Plant nutrition. 1994a; 40(4):593-600. 